\title{
Hubungan Potensi Akal dengan Kreativitas Belajar Siswa Bidang Studi Pendidikan Agama Islam di SMK Kanada Sakura Indonesia (KANSAI) Pekanbaru
}

\author{
MAWARDI AHMAD* \\ SYAHRAINI TAMBAK** \\ RAMLAN NASUTION***
}

\begin{abstract}
*Fakultas Agama Islam (FAI) Universitas Islam Riau (UIR) Pekanbaru Jl. Kaharuddin Nasution, No. 113, Perhentian Marpoyan Pekanbaru 28284

**Fakultas Agama Islam (FAI) Universitas Islam Riau (UIR) Pekanbaru Jl. Kaharuddin Nasution, No. 113, Perhentian Marpoyan Pekanbaru 28284 e-mail: syahraini_tambak@yahoo.co.id

***Fakultas Agama Islam (FAI) Universitas Islam Riau (UIR) Pekanbaru Jl. Kaharuddin Nasution, No. 113, Perhentian Marpoyan Pekanbaru 28284
\end{abstract}

\begin{abstract}
Abstrak: Potensi akal merupakan salah satu hal yang sangat penting yang harus dimiliki oleh setiap individu. Dengan memiliki potensi akal diharapkan seseorang mampu belajar dengan kreatif. Potensi akal yang dimiliki oleh siswa pada dasarnya untuk mengembangkan kreativitas belajar siswa termasuk dalam mempelajari bidang studi pendidikan agama Islam. Tetapi berdasarkan pengamatan penulis siswa SMK Kanada Sakura Indonesia (KANSAI) Pekanbaru masih terdapat gejala-gejala yaitu terdapat sebagaian peserta didik yang kurang berani mengajukan pertanyaan, sebagaian peserta didik yang kurang mampu memberi gagasan, sebagian peserta didik yang kurang memiliki rasa ingin tahu, sebagian peserta didik kurang mampu memberikan alternatif gagasan ketika ada persoalan. Perumusan masalah dalam penelitian ini adalah bagaimana hubungan potensi akal dengan kreativitas belajar siswa bidang studi pendidikan agama Islam di SMK Kanada Sukura Indonesia (KANSAI) Pekanbaru. Tujuan penelitian adalah untuk mengetahui bagaimana hubungan potensi akal dengan kreativitas belajar Siswa bidang studi pendidikan agama Islam di SMK Kanada Sukura Indonesia (KANSAI) Pekanbaru. Jenis Penelitian yang penulis lakukan adalah korelasi. Adapun teknik yang penulis gunakan dalam pengumpulan data adalah angket yang disebarkan kepada 48 responden yang merupakan siswa SMK Kanada Sakura Indonesia (KANSAI) Pekanbaru. Berdasarkan hasil pengolahan dan analisis data yang telah penulis lakukan, maka diperoleh kesimpulan bahwa ada hubungan potensi akal dengan kreativitas belajar Siswa bidang studi Pendidikan Agama Islam di SMK Kanada Sukura Indonesia (KANSAI) Pekanbaru. Hal ini dibuktikan dengan hasil analisis korelasi product moment diperoleh nilai signifikansi $=0,000<0,05$, dan tingkat hubungannya sebesar 0,908.
\end{abstract}

Kata kunci: potensi akal, kreativitas belajar, bidang studi PAI 


\section{PENDAHULUAN}

Kreativitas

mencerminkan

pemikiran divergen yaitu kemampuan yang dapat memberikan bermacammacam alternative jawaban.Kreativitas dapat digunakan untuk memprediksi keberhasilan belajar, namun sebenarnya setiap orang adalah kreatif, dan untuk mendapatkan orang yang demikian perlu adanya latihan dan bimbingan dari orang tua atau pun guru.

Menurut Winkel, dalam kreativitas berfikir atau berfikir kreatif, kreativitas merupakan tindakan berfikir yang menghasilkan gagasan kreatif atau cara berfikir cara yang baru asli, independen, dan imajinatif. Kreativitas dipandang sebuah proses mental. Daya kreativitas menunjukkan pada kemampuan berfikir yang lebih orisinal dibanding dengan kebanyakan orang lain (Ngalim Purwanto, 2003: 153-154).

Pendidikan mempunyai peranan yang sangat menentukan bagi perkembangan dan perwujudan diri individu, terutama bagi pembangunan bangsa dan negara. Kemajuan suatu kebudayaan bergantung kepada cara kebudayaan tersebut mengenali, menghargai, memanfaatkan sumberdaya manusia dan hal ini berkaitan erat dengan kualitas pendidikan yang diberikan kepada anggota masyarakat termasuk peserta didik.

Hal ini sesuai denganUU RI No 20 Tahun 2003 Pasal 3 dalam (Hasbullah, 2012: 307) menjelaskan bahwa pendidkan nasional fungsi mengembangkan dan membentuk kemampuan watak serta peradaban bangsa yang bermartabat dalam rangkamencerdaskan bangsa, bertujuan untuk mencerdaskan bangsa, bertujuan untuk berkembangnya potensi peserta didik agar menjadi manusia yang beriman dan bertaqwa kepada Tuhan Yang Maha Esa, berakhlakmulia, sehat,berilmu, cakap, kreatif, mandiri, dan menjadi warga Negara yang demokratis serta bertanggung jawab.

Tujuan pendidikan pada umumnya ialah menyediakan lingkungan yang memungkinkan anak didik untuk mengembangkan bakat dan kemampuannya secara optimal, sehingga ia dapat mewujudkan dirinya dan berfungsi sepenuhnya, sesuai dengan kebutuhan pribadinya dan kebutuhan masyarakat. Setiap orang mempunyai bakat dan kemampuan yang berbeda-beda dan karena itu membutuhkan pendidikan yang berbeda-beda pula.

Pendidikan bertanggung jawab untuk memandu (yaitu mengidentifikasi dan membina) serta memupuk (yaitu mengembangkan dan meningkatkan) bakat tersebut, termasuk dari mereka yang berbakat istimewa atau memiliki kemampuan dan kecerdasan luar biasa (the gifted and talented).Dulu orang biasanya mengartikan "anak berbakat" sebagai anak yang memiliki tingkat kecerdasan (IQ) yang tinggi.Namun, sekarang makin disadari bahwa yang menetukan keberbakatan bukan hanya inteligensi (kecerdasan) melainkan juga kreativitas dan motivasi untuk berprestasi (Utami Munandar, 1999:6).

Setiap orang seharusnya ingin menjadi kreatif.Kreativitas membuat hidup menjadi lebih menyenangkan, lebih menarik, dan membuat kita dapat mencapai lebih banyak hal.Riset menunjukkan 94 persen anak muda menilai bahwa "pencapaian" adalah hal yang paling penting dalam hidup mereka.Kreativitas adalah keterampilan utama yang di perlukan untuk mencapai sesuatu. Tanpa kreativitas, hanya akan ada pengulangan dan rutinitas. Kedua hal tersebut memang sangat bermanfaat dan membentuk sebagaian besar perilaku kita, namun kreativitas diperlukan untuk mencapai perubahan, 
perbaikan, dan arah tujuan yang baru (E. de Bono, 2008:5).

Kreativitas diartikan secara berbeda-beda oleh para pakar berdasarkan sudut pandang masingmasing.Salah satunya Barron dalam Mohammad Ali dan Mohammad Asrori mendefinisikan kreativitas adalah kemampuan untuk menciptakan sesuatu yang baru. Sesuatu yang baru disini bukan berarti harus sama sekali baru, tetapi dapat juga sebagai kombinasi dari unsur-unsur yang telah ada sebelumnya (Mohammad Ali dan Mohammad Asrori, 2012:41).

Orang kreatif juga di anggap berani mengambil resiko dan kritik, tidak mudah putus asa, dan menghargai keindahan. Kelebihan lain yang dimiliki orang kreatif adalah mereka mampu melihat masalah dengan pandangan berbeda, teguh dengan ide, mampu memilah peluang untuk menfasilisasi maupun menunda keputusan sulit.

Menurut Hamalik (2003:3) pendidikan adalah suatu proses dalam rangka mempengaruhi peserta didik supaya mampu menyesuaikan dirinya dengan lingkungannnya. Dengan demikian akan menimbulkan perubahan dalam dirinya yang memungkinkannya untuk berfungsi di dalam kehidupan bermasyarakat. Pengajaran bertugas mengarahkan proses ini agar sasaran dari perubahan itu dapat tercapai sebagaimana yang diinginkan.

Melalui usaha pendidikan diharapkan kualitas generasi pemuda yang cerdas, kreatif, inovatif dan mandiri dapat terwujud.Namun kenyataanya kreatifitas siswa sekarang ini berkembang lambat dan frekuensi belajar siswa yang kurang.Hal ini disebabkan karena sistem pendidikan yang senantiasa bergantung pada pendidik, sehingga akibatnya siswa kurang bersemangat untuk mencapai prestasi belajar yang lebih tinggi. Siswa kurang memiliki tingkah laku yang kritis bahkan cara berfikir untuk mengeluarkan ide-ide yang sifatnya inovatif pun terkesan lambat.

Hal demikian terjadi di SMK KANSAI, dimana para peserta didiknya kurang memiliki kreativitas belajar. Padahal seharusnya mereka memiliki kreativitas dalam belajar karena guru sudah mengingatkan hal itu saat mengajar. Tapi kenyataanya tidak demikian, hal ini dapat dilihat dari gejala-gejala sebagai berikut:

Terdapat sebagaian peserta didik yang kurang berani mengajukan pertanyaan kepada guru terkait pelajaran yang kurang dipahami; (2) Ada sebagaian peserta didik yang kurang mampu memberi gagasan terhadap persoalan yang dipelajari didalam kelas; (3) Ada sebagian peserta didik yang kurang memiliki rasa ingin tahu terhadap materi yang diajarkan oleh guru; dan (4) Ada sebagian peserta didik ketika guru menyuruh untuk memberikan masukan terhadap masalah yang dipelajari kurang mampu memberikan alternative gagasan.

Mengingat

luasnya permasalahan yang telah digambarkan dalam latar belakang masalah,yang berkaitan dengan pengembangan kreativitas, maka perlu diberikan batasan masalah penelitian yaitu meliputi: Hubungan Potensi Akal dengan Kreativitas Belajar Siswa Bidang Studi Pendidikan Agama Islam di SMK Kanada Sakura Indonesia (KANSAI) Pekanbaru. Adapun masalah penelitian yang dilakukan, yaitu:Bagaimana Hubungan Potensi Akal dengan Kreativitas Belajar Siswa Bidang Studi Pendidikan Agama Islam di SMK Kanada Sakura Indonesia (KANSAI) Pekanbaru? Sedangkan tujuan penelitian ini adalah: Untuk mengetahuiHubungan Potensi Akal dengan Kreativitas Belajar Siswa Bidang Studi Pendidikan Agama Islam di 
SMK Kanada Sakura Indonesia (KANSAI) Pekanbaru.

\section{KONSEP TEORI}

\section{Hakikat Potensi Akal}

Kata potensi itu berasal dari bahasa Inggris yaitu potency, potential dan potentiality, yang mana dari ketiga kata tersebut memilikiarti tersendiri. Kata potency memilikiarti kekuatan,terutama kekuatan yang tersembunyi. Kemudian kata potential memiliki arti yang ditandai oleh potensi, mempunyai kemampuan terpendam untuk menampilkan atau bertindak dalam beberapa hal, terutama hal yang mencakup bakat atau intelegensia. Sedangkan kata potentiality mempunyai arti sifat yang mempunyai bakat terpendam, atau kekuatan bertindak dalam sikap yang pasti dimasa mendatang (HafiAnshari,1996:482).

Berbagai potensi yang ada pada diri manusia semestinya diataur atau dikelola dengan baik, kemudian digunakan secara optimal dalam hidup ini dan akhirnya yang sangat penting adalah mengendalikan potensi-potensi tersebut agar selalu dapat memberikan kesuksesan, kebaikan, kebahagiaan dan keberuntungan dalam hidup, baik di dunia maupun di akhirat nanti.

Bertolak dari pengertian atau definisi diatas, maka dapat dikatakan bahwa potensi adalah kemampuan yang dimiliki setiap pribadi/individu peserta didik yang mempunyai kemungkinan untuk dikembangkan sehingga dapat menjadi kemungkinan yang aktual dan berprestasi (Dirman,dan Cicih Juarsih, 2014:5).

Sedangkan kata akal sudah menjadi kata Indonesia, berasal dari kata Arab al-'Aql (العقل), yang dalam bentuk kata benda. Al-Qur'an hanya membawa bentuk kata kerjanya 'aqaluuh (عقلوه) dalam 1 ayat, ta'qiluun (تعقلون) 1 ayat, 24 ayat, na'qil (نعقل) ya'qiluha (يعقلها) 1 ayat dan ya'qiluun (يعقلون) 22 ayat, kata-kata itu datang dalam arti faham dan mengerti (Tesis, Kadar Bin Muhammd Yusuf, 2005:162). Allah SWT berfirman:

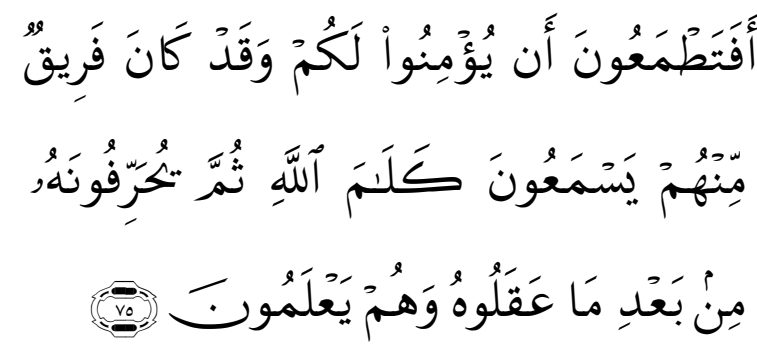

Artinya: "Apakah kamu masih mengharapkan mereka akan percaya kepadamu, padahal segolongan dari mereka mendengar firman Allah, lalu mereka mengubahnya setelah mereka memahaminya, sedang mereka mengetahui? "(QS. AlBaqarah, 2: 75)

Al-Muhasabi mengatakan dalam (Tesis, Kadar Bin Muhammd Yusuf, 2005: 236) akal sebagai kekuatan rohani merupakan pembawaan yang Allahjadikan pada diri manusia sejak lahir, ia sudah ada semenjak "bersatunya" jasmani dan rohani.

Kata 'aql di zaman jahiliyyah dipakai dalam arti kecerdasan praktis (practical intelligence) yang dalam istilah psikologi modern disebut kecakapan memecahkan masalah (problem-solving capacity).Orang berakal, adalah orang yang mempunyai kecakapan untuk menyelesaikan masalah. Bagaimanapun kata 'aqala mengandung arti mengerti, memahami dan berfikir. Akal merupakan pengertian dan pemikiran yangberubah-ubah dalam menghadapi sesuatu, baik yang tampak jelas maupun yang tidak jelas. Dengan potensi akal ini, manusia akan mampu berfikir dan berkreasi menggali dan menemukan ilmu pengetahuan sebagai bagian dari fasilitas yang diberikan kepada manusia untuk fungsi kekhalifahannya. Dan 
potensi akal inilah yang ada dalam diri manusia sebagai sumber kekuatan yang luar biasa dan dahsyat yang tidak dimiliki oleh mahluk lain (Tesis, Wismanto, 2015:120)

Hubungan potensi dengan akal, potensi akal memberi kemampuan kepada manusia untuk memahami simbol-simbol, hal-hal abstrak, menganalisa, membandingkan maupun membuat kesimpuan dan akhirnya memilih maupun memisahkan antara yang benar dan yang salah. Potensi akal ini sebagi organ yang ada dalam diri manusia yang untuk membedakan antara manusia dengan makhluk lain. Akal sebagai potensi manusia dalam pandangan islam itu berbeda dengan otak. Akal disini diartikan sebagai daya pikir yang terdapat dalam jiwa manusia. Akal dalam islam merupak ikatan tiga unsur pikiran, perasaan dan kemauan. Bila ikatan itu tidak ada, maka tidak ada akal itu (Djamaludin Ancok dan Fuad Ansori Suroso: 2011:158).

Berdasarkan pengertian dan penjelasan di atas dapat penulis simpulkan bahwa potensi akal adalah kemampuan dasar manusia yang telah diberikan oleh Allah SWT secara otomatis yang mempunyai kecenderungan untuk dapat berkembang dan dapat dikembangkan melalui daya (akal) yang dimiliki oleh manusia.

\section{potensi akal perspektif al-Qur'an}

Dalam konteks ayat-ayat al-qur'an kata "aql" dapat dipahami sebagai daya untuk memahami dan menggambarkan sesuatu. Dorongan moral dan daya untuk mengambil pelajaran dan kesimpulan serta hikmah, akal memiliki posisi yang sangat mulia. Karena segala pengetahuan diperoleh dari akal, meski demikian bukan berarti akal diberi kebebasan tanpa batas dalam memahami agama. Tidak sedikit ayat yang ayat-ayat yang menganjurkan dan mendorong manusia untuk supaya berfikir dan mempergunakan akalnya, Allah SWT berfirman:

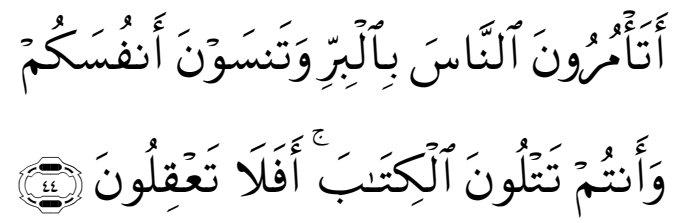

Artinya: "Mengapa kamu suruh orang lain (mengerjakan) kebaktian, sedang kamu melupakan diri (kewajiban) mu sendiri, padahal kamu membaca Al Kitab (Taurat)? Maka tidaklah kamu berpikir?" (Q.S. Al-Baqarah, 2: 44).

Islam memiliki aturan untuk menempatkan akal sebagaimana mestinya. Bagaimanapun, akal yang sehat akan selalu 'cocok dengan syariat Islam dalam permasalahan apapun. Dan Wahyu baik berupa Al-Qur'an dan Hadits bersumber dari Allah SWT, pribadi Nabi Muhammad SAW yang menyampaikan wahyu ini, memainkan peranan yang sangat penting dalam turunnya wahyu.Wahyu merupakan perintah yang berlaku umum atas seluruh umat manusia, tanpa mengenal ruang dan waktu, baik perintah itu disampaikan dalam bentuk umum atau khusus.Apa yang dibawa oleh wahyu tidak ada yang bertentangan dengan akal, bahkan ia sejalan dengan prinsipprinsip akal. Wahyu itu merupakan satu kesatuan yang lengkap, tidak terpisahpisah.Wahyu itu menegakkan hukum menurut kategori perbuatan manusia. baik perintah maupun larangan. Sesungguhnya wahyu yang berupa AlQur'an dan As-Sunnah turun secara berangsur-angsur dalam rentang waktu yang cukup panjang (Harun Nasution, 1982:23)

Namun tidak selalu mendukung antara wahyu dan akal, karena seiring perkembangan zaman akal yang semestinya mempercayai wahyu adalah 
sebuah anugerah dari Allah terhadap orang yang terpilih, terkadang mempertanyakan keaslian wahyu tersebut. Apakah wahyu itu benar dari Allah ataukah hanya pemikiran seseorang yang beranggapan semua itu wahyu. Seperti pendapat Abu Jabbar bahwa akal tak dapat mengetahui bahwa upah untuk suatu perbuatan baik lebih besar dari dalam upah yang ditentukan untuk suatu perbuatan baik lain, demikian pula akal tak mengetahui bahwa hukuman untuk suatu perbuatan buruk lebih besar dari hukuman untuk suatu perbuatan buruk yang lain. Semua itu hanya dapat diketahui dengan perantaraan wahyu. Al-Jubbai berkata wahyulah yang menjelaskan perincian hukuman dan upah yang akan diperoleh manusia di akhirat.

Potensi Akal dalam Al-Qur'an merupakan firman Allah yang diturunkan sebagai hudâ(n) (petunjuk) bagi manusia agar manusia mampu hidup sesuai dengan tujuan Allah menciptakannya. Agar manusia mampu memahami dan mengaplikasikan petunjuk dari al-Qur'an tersebut, maka manusia (baik individu atau kolektif) harus mengkaji, memahami, menghayati, dan menginternalisasikan ajaran-ajaran Al-Qur'an tersebut dalam hati, pikiran, jiwa, dan perilakunya pada seluruh dimensi kehidupannya. Semua isi Al-Qur'an merupakan petunjuk, karena setiap huruf, kata, ayat, dan surat mempunyai makna, baik makna leksikal (etimologis), makna grammatikal (terminologis), maupun makna kontekstual. Oleh karena itu, memahami Al-Qur'an secara komprehensif dan universal harus dilakukan dengan mengkaji keseluruhan Al-Qur'an, dan tidak dapat dilakukan secara parsial atau hanya menitiktekankan pada pemahaman ayat tertentu.

Dalam kaitan dengan hal ini, analisis munâsabah (relasi antar berbagai struktur Al-Qur'an), asbâb alnuzûl, dan tafsir maudhû'i memegang peranan penting. Salah satu tema pokok dalam Al-Qur'an adalah menyangkut hakikat manusia. Pembahasan Al-Qur'an ini menjadi penting, karena salah satu misi Al-Qur'an adalah menyadarkan mengenai posisi, tugas, dan fungsi manusia dalam hubungannya dengan Allah, alam, dan sesama manusia. Selebihnya, Al-Qur'an juga memberikan petunjuk dan bimbingannya agar mampu menjalani kewajiban dan haknya sesuai dengan tata aturan dan tujuan dari penciptaan manusia oleh Allah SWT.

Adapun indikator potensi akal peserta didik adalah: (a) Mudah menangkap pelajaran; (b) Mempunyai ingatan yang kuat; (c) Mempunyai logika dan keterampilan analisis yang kuat; (d) Mampu berfikir abstrak; (e) Mampu membaca tata letak; (f) Mempunyai keterampilan mekanis; (g) Mempunyai keterampilan dan seni; (h) Pintar bersosialisasi; (i) Mampu memahami perasaan manusia; dan (j) Cepat memecahkan soal atau masalah (Dirman dan Cicih juarsih, 2014: 114115).

\section{Kreativitas Belajar Siswa \\ Hakikat Kreativitas}

Kata kreativitas dalam bahasa inggris adalah "create" berarti mengadakan sesuatu yang sebelumnya tidak ada. Jadi, seseorang dapat "menciptakan kekacauan". Artinya seseorang membuat sesuatu kekacauan yang sebelumnya tidak ada (E. de Bono 2008:11). Sedangkan kreativitas menurut kamus besar bahasa Indonesia berasal dari kata dasar kreatif, yaitu memiliki kemampuan untuk menciptakan sesuatu (Anton M. Moeliono, 2007:330).

Kreativitas didefinisikan secara berbeda-beda oleh para pakar 
berdasarkan sudut pandang masingmasing. Perbedaan dalam sudut pandang ini menghasilkan berbagai definisi kreativitas dengan penekanan yang berbeda-beda.

\begin{tabular}{lrr}
\multicolumn{1}{c}{ Menurut } & Elizabet & Hurlock \\
(2002:4) & "Kerativitas & adalah \\
kemampuan & seseorang & untuk
\end{tabular}
menghasilkan komposisi, produk atau gagasan apa saja yang pada dasarnya baru dan sebelumnya tidak dikenal pembuatannya. Ia dapat berupa kegiatan imajinatif atau sintesis pemikiran yang hasilnya bukan perangkuman. Ia mungkin mencakup pembentukan pola baru dan informasi yang diperoleh dari pengalaman yang sebelumnya mencangkokkan hubungan lama ke situasi baru dan mungkin mencakup korelasi baru. Ia harus mempunyai maksud atau tujuan, bukan fantasi semata walaupun merupakan hasil yang sempurna lengkap. Ia mungkin dapat berbentuk produk seni, kesusteraan. Produk ilmiah, atau mungkin bersifat procedural atau meteodologis.

Baron (1982) mendefinisikan kreativitas adalah kemampuan untuk menciptakan sesuatu yang baru. Guilford (1970) menyatakan kreativitas mengacu pada kemampuan yang ditandai dengan ciri-ciri seorang kreatif.Sedangkan Utami Munandar (1992) mendefinisikan kreativitas sebagai berikut."Kreativitas adalah kemampuan yang mencerminkan kelancaran, keluwesan, dan orisinalitas dalam berfikir serta kemmpuan untuk mengolaborasikan sesuatu gagasan" (Muhammad Ali dan Muhammad Asrori, 2012:41).

James J. Gallagher (1985) dalam Yeni Rachmawati dan Euis Kurnia mengatakan "Creativitiis a mental process by which an individual creates new ideal or products, or recombines existing ideas anda produck, in fashion that is novel to him or her" (kreativitas merupakan sesuatu proses mental yang dilakukan individu berupa gagasan ataupun produk baru, atau mengkombinasikan antara keduanya yang pada akhirnya akan melekat pada dirinya) (Yeni Rachmawati dan Euis Kurnia, 2011:13).

Kreativitas sendiri memiliki arti kemampuan untuk menciptakan atau menemukan sesuatu yang baru yang berbeda dengan sebelumnya.Kreativitas merupakan kemampuan interaksi antara individu dan lingkungannya. Seseorang mempengaruhi dan dipengaruhi oleh lingkungan dimana ia berada, dengan demikian perubahan didalam individu maupun didalam lingkungan dapat menunjang atau dapat menghambat upaya kreatif. Salah satu konsep yang amat penting dalam bidang kreativitas adalah hubungan antara kreativitas dan aktualisasi diri.Menurut psikologi humanistik, Abraham Maslow dan Carl Rogers menyatakan bahwa seseorang mengaktualisasikan dirinya apabila seseorang menggunakan semua bakat dan talentanya untuk menjadi apa yang ia mampu menjadikan, mengaktualisasikan, atau mewujudkan potensinya dirinya (Utami Munandar, 2009:19).

Menurut Maslow aktualisasi diri merupakan karakteristik yang fundamental, suatu potensialitas yang ada pada semua manusia saat dilahirkan, akan tetapisering hilang, terhambat atau terpendam dalam proses pembudayaan. Jadi sumber dari kreativitas adalah kecenderungan untuk mengaktualisasikan diri, mewujudkan potensi, dorongan untuk berkembang dan menjadi matang.

Rogers dalam (Utami munandar: 1992:48) mendefinisikan kreativitas sebagai proses munculnya hasil-hasil baru ke dalam suatu tindakan. Hasilhasil baru ini muncul dari sifat-sifat individu yang unik yang interaksi dengan individu lain, pengalaman 
maupun keadaan hidupnya. Kreativitas ini dapat terwujud dalam suasana kebersamaan dan terjadi apabila relasi antar individu ditandai oleh hubunganhubungan yang bermakna.

Kreativitas yang merupakan hasil dari berfikir kreatif sangat penting bagi kehidupan manusia.Utami Munandar mengatakan alasan mengapa kreativitas pada diri siswa perlu dikembangkan (Didin Wahyudin, diakses taanggal 12 Januari 2016 jam 12.05). Pertama, dengan berkreasi maka orang dapat mewujudkan dirinya, dan ini kebutuhan setiap manusia unutuk mewujudkannya.'Kedua, sekalipun setiap orang menganggap bahwa kreativitas itu perlu dikembangkan, namun perhatian terhadap pengembangan kreativitas belum memadai khususnya dalam pendidikan formal.'Ketiga, menyibukkan diri secara kreatif tidak hanya bermanfaat tetapi memberikan kepuasan tersendiri.'Keempat, kreativitas inilah yang memungkinkan manusia untuk meningkatkan kualitas hidupnya.Untuk hal ini perlu disadari bagaimana para pendahulu yang kreatif telah menolong manusia dalam memecahkan berbagai masalah yang menghimpit manusia.

Jadi, dari beberapa pengertian diatas dapat penulis simpulan bahwa kreativitas adalah suatu kemapuan untuk menciptakan sesuatuyang baru yang berbeda dengan sebelumnya, baik berupa gagasan atau karya nyata dengan menggabung-gabungkan unsurunsur yang sudah ada sebelumnya. Hal baru disini adalah sesuatu yang belum pernah dilakukan oleh orang yang bersangkutan, meskipun hal itu merupakan hal yang tidak asing lagi bagi orang lain.

Menurut Utami Munandar (1999:71). Ciri-ciri kepribadian yang kreatif yaitu: 1) Rasa ingin tahuyang mendalam, 2) Sering mengajukan pertanyaan yang baik, 3) Memberikan banyak gagasan, 4) Bebas dalam menyampaikan pendapat, 5) Mempunyai rasa keindahan yang dalam, 6) Memiliki rasa humor yang luas, 7) Mempunyai daya imajinasi, 8) orisinal dalam mengungkapkan gagasan, dan 9) Menonjol dalam salah satu bidang seni. Utami Munandar (2007:71). Mengemukakan secara spesifikasi indikator yang digunakan untuk meningkatkan kreativitas siswa dalam penelitian ini ada 7 indikator.Indikator diatas dapat digambarkan melalui kegiatan dalam tabel dibawah ini.

\section{Hakikat Belajar}

Belajar adalah kegiatan yang berproses dan merupakan unsur yang sangat fundamental dalam penyelenggaraan setiap jenis dan jenjang pendidikan. Ini berarti, bahwa berhasil atau gagalnya pencapaian tujuan pendidikan itu amat bergantung pada proses belajar yang dialami siswa baik ia berada disekolah maupun di lingkungan rumah atau keluarganya sendiri (Muhibbin Syah, 2003:63).

Belajar adalah perubahan tingkah laku atau penampilan, dengan serangkaian kegiatan misalnya dengan membaca, mengamati, mendengarkan, meniru, dan lain sebagainya. Juga belajar itu akan lebih baik, kalau si subjek belajar itu mengalami atau melakukannya, jadi tidak bersifat verbalistik (Sardiman, 2012:20).

Menurut Hamalik dalam belajar mengandung pengertian terjadinya perubahan dari persepsi dan prilaku, termasuk juga perbaikan prilaku, misalnya pemuasan kebutuhan masyarakat dan pribadi secara lengkap (Tohirin, 2005:59).

Menurut Slameto belajar adalah suatu proses usaha yang dilakukan seseorang untuk memperoleh suatu perubahan tingkah laku yang baru secara keseluruhan, sebagai hasil 
pengalamannya sendiri dalam interaksi dengan lingkungan (Slameto, 2010:2).

Menurut Thorndike dalam belajar adalah proses interaksi dalam stimulus dan respon. Stimulus yaitu apa saja yang dapat merangsang terjadinya kegiatan belajar seperti pikiran, perasaan atau hal-hal lain yang dapat di tangkap melalui alat indra. Sedangkan respon yaitu reaksi yang dimunculkan peserta didik ketika belajar, yang juga dapat berupa pikiran, perasaan atau gerakan/tindakan (Asri Budiningsih, 2012:21).

Burton, dalam sebuah buku "The Guidance of Learning Avtivities", merumuskan pengertian belajar sebagai perubahan tingkah laku pada diri individu berkat adanya interaksi antara individu dengan individu dan individu dengan lingkungannya sehingga mereka mampu berinteraksi dengan lingkungannya (Aunurrahman, 2013:35).

Menurut Moreno dalam Slameto, yang terpenting dalam kreativitas belajar itu bukan lah penemuan sesuatu yang belum pernah diketahui orang sebelumnya melainkan bahwa produk kreativitas itu merupakan sesuatu yang baru bagi diri sendiri dan tidak harus merupakan sesuatu yang baru bagi orang lain atau dunia pada umumnya. Misalnya seseorang siswa menciptakan untuk dirinya sendiri suatu hubungan baru dengan siswa atau orang lain(Slameto, 2010:146).

Berdasarkan penjelasan tentang kreativitas dan belajar di atas, maka penulis menyimpulkan kreativitas belajar adalah kemampuan untuk menemukan cara-cara bagi pemecahan problema-problema dengan mengolaborasikan gagasan-gagasan dengan mempergunakan daya khayal, fantasi atau imajinasi serta mampu menguji kebenaran akan gagasan tersebut. Kreativitas belajar adalah kemampuan untuk menemukan cara- cara bagi pemecahan problemaproblema yang dihadapi mahasiswa dalam setuasi belajar yang didasarkan pada tingkah laku siswa guna menghadapi perubahan-perubahan yang tidak dapat dihindari dalam perkembangan proses belajar mahasiswa.

Konsep operasionl ini merupakan konsep yang dipergunakan untukmemberikanpenjelasan terhadap konsep-konsep teoritis agar mudah diteliti dan dipahami.Adapun yang dimaksud dengan potensi akal dalam penelitian ini adalah kemampuandasarmanusiayang telah diberikan

olehAllahSWTsecaraotomatisyang

mempunyai

kecenderunganuntukdapatberkembang dan dapat dikembangkan melalui daya (akal) yang dimiliki oleh manusia. Dan adapun indikatornya adalah sebagai berikut: (1) Potensi Akal, meliputi: (a) Mudah menangkap pelajaran; (b) Mempunyai ingatan yang kuat; (c) Mempunyai logika dan keterampilan analisis yang kuat; (d) Mampu berfikir abstrak; (e) Mampu membaca tata letak; (f) Mempunyai keterampilan mekanis; (g) Mempunyai keterampilan dan seni; (h) Pintar bersosialisasi; (i) Mampu memahami perasaan manusia; dan (j) Cepat memecahkan soal atau masalah.

Berdasarkan penjelasan tentang kreativitas dan belajar di atas, maka penulis menyimpulkan kreativitas belajar adalah kemampuan untuk menemukan cara-cara bagi pemecahan problema-problema dengan mengolaborasikan gagasan-gagasan dengan mempergunakan daya khayal, fantasi atau imajinasi serta mampu menguji kebenaran akan gagasan tersebut. Kreativitas belajar adalah kemampuan untuk menemukan caracara bagi pemecahan problemaproblema yang dihadapi mahasiswa dalam setuasi belajar yang didasarkan 
pada tingkah laku siswa guna menghadapi perubahan-perubahan yang tidak dapat dihindari dalam perkembangan proses belajar mahasiswa.

Untuk mengetahui kreativitas belajar sisiwa dalam proses pembelajaran Pendidikan Agama Islam maka digunakan indikatornya sebagai berikut: (a) Mengajukan pertanyaan; (b) Aktif dalam mengerjakan tugas; (c) Menyatakan pendapat; (d) Memberi banyak gagasan terhadap suatu masalah; (e) Rasa ingin tahu yang yang cukup besar; (f) Menyampaikan jawaban; dan (g) Memiliki alternatif dalam menyelasaikan masalah.

Hipotesis adalah jawaban sementara terhadap pertanyaan sementara (Sugiono,2013:159). Jadi sebuah hipotesis diterima jika faktafakta membenarkan dan akan ditolak jika kenyataan bertolak belakang dengan kenyataan semula. Adapun hipotesis yang diajukan dalam penelitian ini adalah:

Ha : AdaHubungan Potensi Akal dengan Kreativitas Belajar Siswa Bidang Studi Pendidikan Agama Islam di SMK Kanada Sakura Indonesia (KANSAI) Pekanbaru.

Ho : Tidak ada HubunganPotensi Akal dengan Kreativitas Belajar Siswa Bidang Studi Pendidikan Agama Islam di SMK Kanada Sakura Indonesia (KANSAI) Pekanbaru.

\section{METODE}

Berdasarkan permasalahan yang akan diteliti maka penelitian ini termasuk jenis penelitian korelasi. Menurut Hartono (dalam Herlina, 2013 : 30) penelitian korelasi merupakan penelitian yang dilakukan untuk mengetahui ada atau tidaknya suatu hubungan antara dua variabel atau lebih.

Subjek penelitian ini adalah siswa di SMK Kanada Sakura Indonesia (KANSAI) Pekanbaru.Sedangkan objeknya adalah Potensi Akal dengan Kreativitas Belajar Siswa Bidang Studi Pendidikan Agama Islam di SMK Kanada Sakura Indonesia (KANSAI) Pekanbaru.

Dalam Penelitian Ini Populasi Yang Diambil AdalahSiswa kelas X (sepuluh) SMK Kanada Sakura Indonesia (KANSAI) Pekanbaru yang berjumlah 318 orang.Karena populasi lebih dari 100 maka diambil 15\% yakni 48 orang siswa (Suharsimi Arikunto, 2006: 134).

Teknik pengumpulan data pada penelitian ini adalah angket dan dokumentasi. Angket merupakan kumpulan pertanyaan atau perrnyataan yang diajukan secara tertulis kepada responden dan cara menjawabnya juga dilakukan dengan tertulis (Rizal Dairi, 2010: 66). Dokumentasi adalah mencari data berupa catatan, buku, surat kabar, agenda, dan lain-lain (Suharsimi Arikunto, 2013 : 201).

Data yang telah terkumpul perlu diolah terlebih dahulu, tujuannya adalah untuk menyederhanakan seluruh data yang terkumpul, menyajikannya dalam susunan yang baik kemudian dianalisis (Rizal Dairi, 2010: 77-78). Pada tahap pengolahan data, ada beberapa kegiatan yang perlu dilakukan, antara lain: (1) Penyuntingan (editing). Data yang telah dikumpulkan harus diperiksa apakah terdapat kekeliruan dalam pengisian.Kegiatan mengoreksi atau melakukan pengecekan ini disebut editing; (2) Pengkodean (coding). Pengkodean adalah pemberian tanda, simbol, dan kode pada tiap data yang termasuk dalam kategori yang sama. Tanda yang digunakan dapat berupa angka atau huruf; (3) Skoring. Memberikan skor terhadap butir-butir pernyataan atau pertanyaan 
yang terdapat dalam angket setelah penulis melakukan tahap editng, butir yang terdapat dalam angket ada 5 (lima). Adapun pemberian skor untuk setiap jawaban adalah: (a) Sangat Setuju (SS) skor: 5 (lima); (b) Setuju (S) skor: 4 (empat); (c) Ragu-ragu (RR) skor: 3 (tiga); (d) Tidak Setuju (TS) skor: 2 (dua); dan (e) Sangat Tidak Setuju (STS) skor 1 (satu); dan (4) Pentabulasian (tabulating). Pentabulasian adalah menyusun data dalam bentuk tabel.Jawaban-jawaban yang serupa dikelompokkan dengan teliti, kemudian dihitung, ditelly, dan dijumlahkan sesuai dengan banyaknya peristiwa, gejala, dan item.Kegiatan tersebut dilaksanakan sampai terwujud tabel-tabel yang berguna (Rizal Dairi, 2010: 78).

Sebelum

penelitian

dilaksanakanmaka langkah yang utama adalah melakukanuji coba instrumen penelitian.Uji coba dari butir-butir instrumen pada kedua variabel untuk menguji layak atau tidaknya instrumen yang digunakan dalam penelitian.Untuk itu hasil uji coba harus dicari validitas dan realibilitasnya.

Uji validitas merupakan uji instrumen data untuk mengetahui seberapa cermat suatu item dalam mengukur apa yang ingin di ukur. Item dapat dikatakanvalid jika adanya korelasi yang signifikan dengan skor totalnya, hal ini menunjukkan adanya dukungan item tersebut dalam mengungkapkan sesuatu yang diungkapkan.Item biasanya berupa pertanyaan atau pernyataan yang ditujukan kepada responden dengan menggunakan kuisioner (angket)dengan tujuan untuk mengungkapkan sesuatu (Duwi Priyatno, 2014:51).

Instrument yang reliabel adalah instrumen yang bila digunakan beberapa kali untuk mengukur objek yang sama, akan menghasilkan data yang sama. Dalam penelitian ini uji reliabilitas instrumen dilakukan dengan internal consistensi yaitu mencobakan instrumen sekali saja, kemudian data yang diperoleh dianalisis dengan teknik tertentu.Hasil analisisnya dapat digunakan untuk memprediksi reliabilitas instrumen.

Pengujian reliabel instrumen dapat dilakukan dengan menggunakan bantuan program SPSS 20. Uji reliabilitas dilakukan dengan menggunakan metode Cronbach Alpha.Dalam metode ini item yang valid saja yang dimasukkan pengujian. Untuk menentukan apakah instrumen reliable atau tidak menggunakan batasan yaitu reliabilitas kurang dari 0,6 adalah kurang baik, sedangkan 0,6 sampai 0,79 dapat diterima dan di atas 0,8 sampai 1 adalah baik (memiliki konsistensi yang tinggi) (Duwi Priyatno, 2014:64).

Analisis korelasi pearson atau dikenal juga dengan korelasi product moment adalah analisis untuk mengukur keeratan hubungan secara linier antara dua variabel yang mempunyai distribusi data normal (Duwi Priyatno, 2014: 123).

Untuk menganalisis data tentang hubungan potensi akal dengan kreatifitas belajar siswa bidang studi pendidikan agama Islam, dan untuk menentukan apakah variabel $\mathrm{X}$ dengan variabel $\mathrm{Y}$ terdapat hubungan yang signifikan, maka peneliti menggunakan rumus korelasi product moment yaitu:

$=\frac{n\left(\sum X Y\right)-\left(\sum X\right) \cdot\left(\sum Y\right)}{\sqrt{\left\{n \cdot \sum X^{2}-\left(\sum X\right)^{2}\right\} \cdot\left\{n \cdot \sum Y^{2}-\left(\sum Y\right)^{2}\right\}}}$

Keterangan:

$\mathrm{r}_{\mathrm{xy}}=$ Angka indeks korelasi antara variabel $\mathrm{X}$ dan variabel $\mathrm{Y}$.

$\mathrm{n} \quad=$ Jumlah sampel.

$\sum \mathrm{X}^{2}=$ Jumlah kuadrat variabel $\mathrm{X}$.

$\sum \mathrm{Y}^{2}=$ Jumlah kuadrat variabel $\mathrm{Y}$.

$\sum \mathrm{X}=$ Jumlah variabel $\mathrm{X}$.

$\sum \mathrm{Y}=$ Jumlah variabel $\mathrm{Y}$. 
$\sum \mathrm{XY} \square=$ Jumlah perkalian antara variabel $\mathrm{X}$ dan $\mathrm{Y}$.

Kemudian untuk pengujian signifikansi antara variabel X dengan variabel $\mathrm{Y}$ dilakukan dengan kriteria menggunakan $r$ tabel pada tingkat signifikansi 0,05 . Jika nilai positif dan $r_{\text {hitung }} \geq r_{\text {tabel }}$ maka terdapat hubungan yang signifikan antara varibael $\mathrm{X}$ dan variabel $\mathrm{Y}$, jika $\mathrm{r}_{\text {hitung }} \leq \mathrm{r}_{\text {tabel }}$ maka tidak terdapat hubungan yang signifikan antara variabel $\mathrm{X}$ dan variabel $\mathrm{Y}$.

Ketentuan nilai $r$ tidak lebih dari harga $(-1 \leq \mathrm{r} \leq 1)$.Maksudnya adalah nilai $r$ terbesar adalah +1 dan nilai $r$ terkecil adalah -1 . Apabila $r=-1$ artinya korelasinya negatif sempurna; $r=0$ artinya tidak ada korelasi; dan $r=1$ artinya korelasinya sangat kuat.

\section{HASIL}

\section{Gambaran Umum Lokasi Penelitian}

Sejarah Singkat SMK KANSAI Pekanbaru

Dengan

Alhamdulillah dan rasa syukur kehadirat Allah SWT atas rahmat dan karunianya sehingga SMK KANSAI Pekanbaru dapat berdiri diawal tahun 2003/2004 dengan tujuan untuk menjadikan tempat menimba ilmu pengetahuan atau sumber daya manusia. SMK KANSAI Pekanbaru berdiri dibawah naungan Yayasan Kanada Sakura Indonesia (KANSAI).

Dengan persetujuan Wali Kota Pekanbaru Nomor: 96 Tahun 2003 Tanggal 27 Mei 2003, dari tahun 2003 SMK KANSAI Pekanbaru sampai tahun 2007, mengontrak gedung AKRI yang terletak dijalan Damai Ujung No.120, Kecamatan Tampan (Pimpinan/ Kepala Sekolah dan Kasub Bag, Tata Usaha).

\section{Visi dan Misi SMK KANSAI Pekanbaru \\ Adapun visi SMK Kansai Pekanbaru adalah: "Output Dan Warga Sekolah}

Dapat HidupLayak Di Tengah-Tengah Masyarakat Dan Mampu Menghadapi Tantangan Di Era Globalisasi Serta Peduli Lingkungan”. Sedangkan misi SMK Kansai adalah: (1) Melahirkan Output Berkualitas Yang BerorientasiKepada Dunia Kerja Dengan Kriteria: (a) Takwa Kepada Tuhan Yang Maha Esa; (b) Mandiri; (c) Berbudi Luhur, Energik, Produktif Dan Mampu Beradaptasi Mewujudkan Iklim Kerja Sehat Sesuai Perkemembangan Zaman Dan Pembangunan Bangsa; dan (d) Terwujudnya Peserta Didik Yang Mencintai Keindahan, Kerindangan, Kebersihan Serta Kesehatan Lingkungan. (2) Mengembangkan Semua Pontensi Yang Ada Secara Efektif, Efisien, dan Mampu: (a) Melahirkan Output Yang Berkualitas Dan Menyalurkan Kedunia Kerja; (b)Menyiapkan Output Yang Ingin Melanjutkan Ke Perguruan Tinggi; (c) Merebut Dan Menciptakan Peluang Kerja; (d) Mengupayakan Peningkatan Kesejahteraan Warga Sekolah; dan (e) Berperan Aktif Dalam Pencegahan Kerusakan Dan Pencemaran Lingkungan Serta Pelestariannya.

\section{Kondisi Pendidikan Guru}

Pada tahun ajaran 2015/2016 ketika penelitian ini dilaksanakan, guruguru di SMK KANSAI Pekanbaru berjumlah 64 orang, yang merupakan lulusan D3, S1 dan S2 pada bidang keahlian masing-masing.

\section{Kondisi Siswa}

Adapun kondisi siswa/I SMK Kansai Pekanbaru setiap tahunnya mengalami perubahan baik berkurang maupun bertambah, pada tahun ajaran ini sisiwa/ I di SMK KANSAI Pekanbaru berjumlah 1.088 siswa untuk lebih jelasnya lagi akan dipaparkan dibawah ini selama 3 tahun terakhir. 
Tabel 1: Data Kondisi Sisiwa/i

\begin{tabular}{|c|c|c|c|c|c|c|c|c|c|}
\hline \multirow[t]{3}{*}{ Kelas } & \multicolumn{9}{|c|}{ Tahun Ajaran } \\
\hline & \multicolumn{3}{|c|}{$2013 / 2014$} & \multicolumn{3}{|c|}{$2014 / 2015$} & \multicolumn{3}{|c|}{$2015 / 2016$} \\
\hline & L & $\mathbf{P}$ & Jumlah & $\mathbf{L}$ & $\mathbf{P}$ & Jumlah & $\mathbf{L}$ & $\mathbf{P}$ & Jumlah \\
\hline $\mathrm{X}$ & 230 & 55 & 285 & 243 & 61 & 303 & 237 & 81 & 318 \\
\hline $\mathrm{XI}$ & 320 & 150 & 470 & 360 & 169 & 529 & 239 & 58 & 297 \\
\hline XII & 230 & 140 & 370 & 246 & 161 & 407 & 326 & 163 & 489 \\
\hline Jumlah & & & 1.125 & & & 1.239 & & & 1.104 \\
\hline
\end{tabular}

Sumber Data: Tata Usaha SMK KANSAI Pekanbaru 2016

\section{Hasil Penelitian}

Data yang akan disajikan pada penyajian hasil penelitian ini adalah data yang dikumpulkan dari lapangan. Adapun teknik pengumpulan data yang digunakan adalah angket dan dokumentasi.Hasil angket yang telah diperoleh diharapkan dapat menunjukkan bagaimana hubungan potensi akal dengan kreativitas belajar siswa bidang studi pendidikan agama Islam di SMK KANSAI Pekanbaru.

Angket ini diberikan kepada 48 Responden yang menjadi sampel dalam penelitian. Dalam angket tersebut diberikan lima alternatif jawaban ( sangat setuju, setuju, ragu-ragu, tidak setuju, sangat tidak setuju) yang dapat dipilih oleh siswa sesuai dengan pernyataan yang diajukan.

Kemudian data akan disajikan dalam bentuk tabel. Hal ini dilakukan untuk mempermudah penyajian data sehingga mudah dipahami. Adapun data dari hasil angket tersebut dapat dilihat pada tabel berikut :

Tabel 2: Rekapitulasi Hasil Angket Potensi Akal (Variabel X)

\begin{tabular}{|c|c|c|c|c|c|c|c|}
\hline No & Pernyataan & SS & $\mathbf{S}$ & $\mathbf{R R}$ & TS & STS & Jumlah \\
\hline \multicolumn{8}{|c|}{ Mudah Menangkap Pelajaran } \\
\hline 1. & $\begin{array}{l}\text { Saya tidak merasa kesulitanuntuk } \\
\text { menerima pelajaran yang diberikan } \\
\text { oleh guru PAI }\end{array}$ & 22 & 22 & 3 & 0 & 1 & 48 \\
\hline 2. & $\begin{array}{l}\text { Dari materi pembelajaran yang telah } \\
\text { dijelaskan oleh guru PAI sangat } \\
\text { mudah saya pahami }\end{array}$ & 11 & 26 & 8 & 2 & 1 & 48 \\
\hline \multicolumn{8}{|c|}{ Mempunyai Ingatan Yang Kuat } \\
\hline 3. & $\begin{array}{l}\text { Saya ingat semua materi } \\
\text { pembelajaran yang disampaikan oleh } \\
\text { guru PAI }\end{array}$ & 6 & 24 & 17 & 0 & 1 & 48 \\
\hline 4. & $\begin{array}{l}\text { Saya sesang sekali ketika guru PAI } \\
\text { bertanya pelajaran yang telah berlalu }\end{array}$ & 10 & 27 & 8 & 2 & 1 & 48 \\
\hline 1 & 2 & 3 & 4 & 5 & 6 & 7 & 8 \\
\hline & $\begin{array}{c}\text { Mempunyai Logika Dan } \\
\text { Keterampilan Analisis Yang Kuat } \\
\end{array}$ & & & & & & \\
\hline
\end{tabular}




\begin{tabular}{|c|c|c|c|c|c|c|c|}
\hline 5. & $\begin{array}{l}\text { Ketika guru PAI memberikan latihan } \\
\text { soal, saya dapat mengerjakannya } \\
\text { dengan baik dan benar }\end{array}$ & 16 & 19 & 11 & 1 & 1 & 48 \\
\hline \multirow[t]{2}{*}{6.} & $\begin{array}{l}\text { Saya tidak keberatan untuk } \\
\text { menerima tugas-tugas yang } \\
\text { menantang }\end{array}$ & 14 & 21 & 11 & 2 & 0 & 48 \\
\hline & \multicolumn{7}{|l|}{ Mampu Berfikir Abstrak } \\
\hline 7. & $\begin{array}{l}\text { Bila guru PAI memberikan gambar, } \\
\text { cerita, atau masalah maka saya dapat } \\
\text { memberikan penafsiran yang } \\
\text { beragam terhadap soal gambar atau } \\
\text { cerita tersebut }\end{array}$ & 11 & 22 & 14 & 0 & 1 & 48 \\
\hline 8. & $\begin{array}{l}\text { Jika diberi suatu masalah, saya dapat } \\
\text { memikirkan macam-macam cara } \\
\text { yang berbeda untuk memecahkan } \\
\text { masalah tersebut }\end{array}$ & 8 & 26 & 11 & 1 & 2 & 48 \\
\hline \multicolumn{8}{|c|}{ Mampu Membaca Tata Letak } \\
\hline 9. & $\begin{array}{l}\text { Ketika guru PAI mengajarkan } \\
\text { mengajarkan pembelajaran, saya } \\
\text { mampu membuat kerangka untuk } \\
\text { mempermudah pemahaman }\end{array}$ & 5 & 23 & 17 & 1 & 2 & 48 \\
\hline & Mempunyai Keterampilan Mekanis & & & & & & \\
\hline 10. & $\begin{array}{l}\text { Saya mampumenerapkan materi } \\
\text { pembelajaran yang diberikan oleh } \\
\text { guru PAI secara tepat. }\end{array}$ & 7 & 25 & 11 & 2 & 3 & 48 \\
\hline 11. & $\begin{array}{l}\text { Saya mampu melaksanakan petunjuk- } \\
\text { petunjuk pembelajaran yang } \\
\text { diberikan oleh guru secara baik dan } \\
\text { benar. }\end{array}$ & 10 & 26 & 8 & 2 & 2 & 48 \\
\hline
\end{tabular}

\section{Mempunyai Keterampilan Dan}

Seni

12. Saya senang mengolah materi pembelajaran dengan berbagai

$\begin{array}{llllll}10 & 29 & 6 & 1 & 2 & 48\end{array}$
variasi untuk meningkatkan pemahaman.

\begin{tabular}{|c|c|c|c|c|c|c|c|}
\hline 1 & 2 & 3 & 4 & 5 & 6 & 7 & 8 \\
\hline \multicolumn{8}{|c|}{ Pintar Bersosialisasi } \\
\hline 13. & $\begin{array}{l}\text { Saya senang mendiskusikan materi } \\
\text { pembelaiaran dencan teman-teman. }\end{array}$ & 21 & 19 & 5 & 1 & 2 & 48 \\
\hline 14. & $\begin{array}{l}\text { Saya senang bergaul dengan teman- } \\
\text { teman tanpa membeda-bedakan ras } \\
\text { dan suku. }\end{array}$ & 29 & 15 & 2 & 0 & 2 & 48 \\
\hline \multicolumn{8}{|c|}{$\begin{array}{c}\text { Mampu Memahami Perasaan } \\
\text { Manusia }\end{array}$} \\
\hline 15. & $\begin{array}{l}\text { Saya bisa memahami kesulitan } \\
\text { teman-teman dalam belajar dan akan } \\
\text { membantunya. }\end{array}$ & 14 & 24 & 7 & 1 & 2 & 48 \\
\hline
\end{tabular}


16. Ketika ada teman merasa kesulitan

$\begin{array}{llllll}16 & 24 & 4 & 2 & 2 & 48\end{array}$ dalam belajar, dengan senang hati saya akan membantunya walaupun tidak diminta.

\begin{tabular}{|c|c|c|c|c|c|c|c|}
\hline \multicolumn{2}{|r|}{$\begin{array}{c}\text { Cepat Memecahkan Soal Atau } \\
\text { Masalah }\end{array}$} & \multirow[b]{2}{*}{7} & \multirow[b]{2}{*}{21} & \multirow[b]{2}{*}{15} & \multirow[b]{2}{*}{2} & \multirow[b]{2}{*}{3} & \multirow[b]{2}{*}{48} \\
\hline 17. & $\begin{array}{l}\text { Ketika ada soal yang diberikan oleh } \\
\text { guru PAI, saya dapat } \\
\text { menyelesaikannya dengan benar } \\
\text { sebelum teman-teman yang lain } \\
\text { selesai. }\end{array}$ & & & & & & \\
\hline 18. & $\begin{array}{l}\text { Saya dapat mengerjakan tugas belajar } \\
\text { dengan cepat dan benar tanpa } \\
\text { bantuan orang lain. }\end{array}$ & 8 & 17 & 15 & 4 & 4 & 48 \\
\hline \multicolumn{2}{|r|}{ Jumlah } & $\begin{array}{c}22 \\
5\end{array}$ & $\begin{array}{c}41 \\
0\end{array}$ & 173 & 24 & 32 & 864 \\
\hline
\end{tabular}

Berdasarkan tabel 7 di atas terlihat bahwa jawaban siswa yang menyatakan setuju lebih banyak yaitu 410, ini menunjukkan siswa telah memiliki potensi akal yang baik.Dan hanya sebagian siswa yang belum memiliki potensi akal yang baik yang dapat dilihat dari jawaban siswa yang menyatakan tidak setuju yang paling sedikit yaitu 24 .

Tabel 3 : Rekapitulasi Hasil Angket Kreatifitas Belajar Siswa Bidang Studi Pendidikan Agama Islam (Variabel Y)

No Pernyataan $\begin{array}{llllll}\text { SS } & S & \text { RR } & \text { TS } & \text { STS Jumlah }\end{array}$

\section{Mengajukan Pertanyaan}

1. Ketika ada materi pelajaran yang kurang saya pahami maka saya bertanyaan kepada guru.

$\begin{array}{llllllll}\text { 2. } & \text { Saya senang melakukan Tanya jawab } & 17 & 26 & 3 & 0 & 2 & 48\end{array}$ kepada guru PAI untuk menambah pemahaman

\section{Aktif Dalam Mengerjakan Tugas}

3. Bila saya diberi soal PAI dari pokok bahasan yang sudah saya pelajari maka saya dapat langsung memikirkan langkah-langkahnya penyesaiannya.

\begin{tabular}{llllllll}
\hline 4. & Tugas yang diberikan oleh guru PAI & 12 & 27 & 6 & 1 & 2 & 48
\end{tabular} saya kerjakan dengan sendiri 


\begin{tabular}{|c|c|c|c|c|c|c|c|}
\hline 5. & $\begin{array}{l}\text { Saya berani mengeluarkan argument } \\
\text { dalam menyelesaikan pertanyaan } \\
\text { dari guru PAI }\end{array}$ & 9 & 22 & 14 & 1 & 2 & 48 \\
\hline 6. & $\begin{array}{l}\text { Saya tidak senang jika belum } \\
\text { menaggapi pertanyaan guru PAI } \\
\text { maupun teman }\end{array}$ & 7 & 25 & 10 & 4 & 2 & 48 \\
\hline \multicolumn{8}{|c|}{$\begin{array}{c}\text { Memberi Banyak Gagasan } \\
\text { Terhadap Suatu Masalah } \\
\end{array}$} \\
\hline 7. & $\begin{array}{l}\text { Ketika ada masalah saya selalu } \\
\text { memberikan banyak gagasan untuk } \\
\text { memecahkan masalah tersebut }\end{array}$ & 4 & 30 & 11 & 0 & 3 & 48 \\
\hline 8. & $\begin{array}{l}\text { Dalam membahasa atau } \\
\text { mendiskusikan suatu masalah, saya } \\
\text { selalu mempunyai tanggapan berbeda } \\
\text { dengan apa yang di ungkapkan oleh } \\
\text { teman saya }\end{array}$ & 5 & 33 & 7 & 1 & 2 & 48 \\
\hline \multicolumn{8}{|c|}{ Rasa Ingin TahuYang Cukup Besar } \\
\hline 9. & $\begin{array}{l}\text { Jika ada soal PAI yang sulit saya } \\
\text { selesaikan, saya tidak mau menyerah } \\
\text { begitu saja, melainkan saya kembali } \\
\text { mempelajari materipelajaran yang } \\
\text { berhubungan dengan soal tersebut }\end{array}$ & 10 & 32 & 4 & 0 & 2 & 48 \\
\hline 10. & $\begin{array}{l}\text { Jika ada penjelasan guru PAI yang } \\
\text { kurang jelas, saya langsung } \\
\text { menanyakannya }\end{array}$ & 12 & 27 & 7 & 0 & 2 & 48 \\
\hline \multicolumn{8}{|c|}{ Menyampaikan Jawaban } \\
\hline 11. & $\begin{array}{l}\text { Merasa gugup dan cemas waktu saya } \\
\text { menghadapi ujian, karena takut tidak } \\
\text { dapatjawaban pertanyaan } \\
\text { sebagaimana mestinya }\end{array}$ & 7 & 22 & 15 & 2 & 2 & 48 \\
\hline 12. & $\begin{array}{l}\text { Saya senang diam dalam proses } \\
\text { belajar mengajar daripada } \\
\text { memberikan jawaban yang salah }\end{array}$ & 13 & 16 & 9 & 4 & 6 & 48 \\
\hline \multicolumn{8}{|c|}{$\begin{array}{c}\text { Memiliki Alternatif Dalam } \\
\text { Menyesaikan Masalah }\end{array}$} \\
\hline 13. & $\begin{array}{l}\text { Pada saat menyelesaikan masalah, } \\
\text { saya mampu memikirkan jawaban } \\
\text { yang tidak pernah dipikirkan oleh } \\
\text { orang lain. }\end{array}$ & 11 & 27 & 8 & 0 & 2 & 48 \\
\hline \multirow[t]{2}{*}{14.} & $\begin{array}{l}\text { Saya tidak merasa kesulitan untuk } \\
\text { menyelesaikan persoalan-persoalan } \\
\text { dengan jawaban yang benar. }\end{array}$ & 12 & 19 & 14 & 1 & 2 & 48 \\
\hline & Jumlah & 153 & 350 & 12 & 15 & 33 & 677 \\
\hline
\end{tabular}

Sumber data : Hasil Olahan data lapangan, 2016 
Berdasarkan tabel 8 di atas terlihat bahwa jawaban siswa yang menyatakan setuju lebih banyak yaitu 350, ini menunjukkan siswa telah memiliki kreativitas belajar yang baik. Dan hanya sebagian siswa yang belum memiliki kreativitas belajar yang baik yang dapat dilihat dari jawaban siswa yang menyatakan tidak setuju yang paling sedikit yaitu 15

\section{Analisis Data}

\section{Uji Validitas dan Reliabilitas}

Untuk menguji kehandalan dari angket yang digunakan dalam penelitian ini maka dilakukan uji validitas dan reliabilitas pada setiap variabel penelitian dengan tujuan untuk memperoleh data yang baik.

Adapun hasil pengujian validitas dan reliabilitas instrumen dapat dilihat pada rekapitulasi tabel berikut :

Tabel 4 : Hasil Rekapitulasi Validitas Variabel Potensi Akal (X)

\begin{tabular}{cccc}
\hline Pernyataan & $\begin{array}{c}\text { Nilai } \\
\text { Probabilitas }\end{array}$ & $\begin{array}{c}\text { Taraf Signifikansi } \\
(\boldsymbol{\alpha}=\mathbf{0 , 0 5})\end{array}$ & Keteragan \\
\hline P1 & 0.000 & 0,05 & Valid \\
\hline P2 & 0.001 & 0,05 & Valid \\
\hline P3 & 0.000 & 0,05 & Valid \\
\hline P4 & 0.000 & 0,05 & Valid \\
\hline P5 & 0.000 & 0,05 & Valid \\
\hline P6 & 0.023 & 0,05 & Valid \\
\hline P7 & 0.001 & 0,05 & Valid \\
\hline P8 & 0.000 & 0,05 & Valid \\
\hline P9 & 0.000 & 0,05 & Valid \\
\hline P10 & 0.116 & 0,05 & Valid \\
\hline P11 & 0.003 & 0,05 & Valid \\
\hline P12 & 0.014 & 0,05 & Vidak Valid \\
\hline P13 & 0.059 & 0,05 & Valid \\
\hline P14 & 0.000 & 0,05 & Valid \\
\hline P15 & 0.000 & 0,05 & Valid \\
\hline P16 & 0.023 & 0,05 & Valid \\
\hline P17 & 0.000 & 0,05 & Valid \\
\hline P18 & 0.000 & 0,05 & Valid \\
\hline P19 & 0.002 & 0,05 & \\
\hline P20 & 0.000 & 0,05 & \\
\hline P11 & & \\
\hline
\end{tabular}

Sumber: Hasil Olahan SPSS 20, 2016

Item dalam instrumen dikatakan valid jika signifikansi $<0,05$, tetapi jika signifikansi $>0,05$ item tidak valid.

Berdasarkan tabel 9 di atas, dari 20 pernyataan hanya 2 item pernyataan yang tidak valid. Karena memiliki nilai probabilitas atau signifikansi lebih besar $>0,05$ yaitu item $10,(0,116>$ $0,05)$, dan item $13(0,059>0,05)$. Hasil ini diperoleh melalui SPSS 20, dengan demikian dalam penelitian ini hanya menggunakan 18 item pernyataan potensi akal.

Kemudian instrumen yang sudah valid diuji kembali dengan menggunakan SPSS 20 untuk mengetahui tingkat reliabilitasnya, di mana item yang masuk pengujian adalah item yang valid saja.

Adapun hasil uji instrumen tersebut dengan menggunakan SPSS 20 adalah sebagai berikut : 
Tabel 5 : Hasil Uji Reliabilitas Variabel Potensi Akal (X)

\section{Reliability Statistics}

\section{Cronbach's Alpha}

0,944
$\mathrm{N}$ of Items

18

Sumber data : Olah data SPSS 20

Berdasarkan tabel 10 di atas, dapat diketahui bahwa seluruh instrumen dinyatakan reliabel. Sesuai dengan teori yang telah dijelaskan pada bab III, sebuah instrumen dinyatakan reliabel jika hasil Cronbach's Alpha menunjukkan angka minimal 0,6 dan nilai Cronbach's Alpha pada tabel di atas adalah 0,944 dengan kriteria baik (memiliki konsistensi yang tinggi). Hal ini menunjukkan bahwa 0,944> 0,6 sehingga intrumen yang telah diuji dapat digunakan sebagai instrumen penelitian.

Tabel 6: Hasil Rekapitulasi Validitas Kreativitas Belajar Siswa Bidang Studi Pendidikan Agama Islam (Y)

\begin{tabular}{cccc}
\hline Pernyataan & $\begin{array}{c}\text { Nilai } \\
\text { Probabilitas }\end{array}$ & $\begin{array}{c}\text { Taraf Signifikansi } \\
(\mathbf{\alpha}=\mathbf{0 , 0 5})\end{array}$ & Keterangan \\
\hline $\mathbf{1}$ & $\mathbf{2}$ & $\mathbf{3}$ & $\mathbf{4}$ \\
\hline P1 & 0,000 & 0,05 & Valid \\
\hline P2 & 0,000 & 0,05 & Valid \\
\hline P3 & 0,000 & 0,05 & Valid \\
\hline P4 & 0,000 & 0,05 & Valid \\
\hline P5 & 0,000 & 0,05 & Valid \\
\hline P6 & 0,000 & 0,05 & Valid \\
\hline P7 & 0,000 & 0,05 & Valid \\
\hline P8 & 0,000 & 0,05 & Valid \\
\hline P9 & 0,000 & 0,05 & Valid \\
\hline P10 & 0,000 & 0,05 & Valid \\
\hline P11 & 0,000 & 0,05 & Valid \\
\hline P12 & 0,000 & 0,05 & Valid \\
\hline P13 & 0,000 & 0,05 & Valid \\
\hline P14 & 0,000 & 0,05 & Valid \\
\hline
\end{tabular}

Item dalam instrumen dikatakan valid jika signifikansi $<0,05$, tetapi jika signifikansi $>0,05$ item tidak valid.

Berdasarkan tabel 11 di atas, dari 14 pernyataan semuanya valid. Karena nilai probabilitas atau signifikansi seluruh item pernyataan < 0,05 . Hasil ini diperoleh melalui SPSS 20, dengan demikian penelitian ini menggunakan 14 item pernyataan kreativitas belajar.
Kemudian instrumen yang sudah valid diuji kembali dengan menggunakan SPSS 20 untuk mengetahui tingkat reliabilitasnya, di mana item yang masuk pengujian adalah item yang valid saja.

Adapun hasil uji instrumen tersebut dengan menggunakan SPSS 20 adalah sebagai berikut : 
Tabel 7 : Hasil Uji Reliabilitas Variabel Kreativitas Belajar Siswa Bidang Studi Pendidikan Agama Islam (Y)

Reliability Statistics

\begin{tabular}{c|c}
\hline Cronbach's Alpha & N of Items \\
\hline 0,977 & 14 \\
\hline
\end{tabular}

Berdasarkan tabel 12 di atas, dapat diketahui bahwa seluruh instrumen dinyatakan reliabel. Sesuai dengan teori yang telah dijelaskan pada bab III, sebuah instrumen dinyatakan reliabel jika hasil Cronbach's Alpha menunjukkan angka minimal 0,6 dan nilai Cronbach's Alpha pada tabel di atas adalah 0,977 dengan kriteria baik (memiliki konsistensi yang tinggi). Hal ini menunjukkan bahwa 0,977 >0,6 sehingga intrumen yang telah diuji dapat digunakan sebagai instrumen penelitian.

\begin{abstract}
Hubungan Potensi Akal dengan Kreativitas Belajar

Angket yang telah diperoleh kemudian diolah, dianalisis, dan disimpulkan menggunakan teknik analisis Korelasi Pearson.Teknik analisis Korelasi Pearson ini digunakan untuk menganalisis data tentang keeratan hubungan potensi akal dengan kreativitas belajar siswa bidang studi pendidikan agama Islam di SMK KANSAI Pekanbaru. Adapun hasil yang diperoleh dari SPSS 20 adalah sebagai berikut :
\end{abstract}

Tabel 8 :Hasil Analisis Korelasi Pearsonantara Variabel Potensi Akal (X) dengan Variabel Kreativitas Belajar Siswa Bidang Studi Pendidikan Agama Islam (Variabel Y)

\begin{tabular}{llrr}
\hline & & Potensi Akal & Kreativitas Belajar \\
\hline \multirow{4}{*}{ Potensi Akal } & Pearson & 1 & $.908^{* *}$ \\
& Correlation & & .000 \\
& Sig. (2-tailed) & 48 & 48 \\
& $\mathrm{~N}$ & & 1 \\
\multirow{4}{*}{ Kreativitas Belajar } & Pearson & \multicolumn{2}{c}{4} \\
& Correlation & $.908^{* *}$ & 48 \\
& Sig. (2-tailed) & .000 & \\
& $\mathrm{~N}$ & 48 & \\
\hline
\end{tabular}

**. Correlation is significant at the 0.01 level (2-tailed).

Tabel di atas menyajikan hasil koefisien korelasi Pearson Product Moment antara dua variabel yaitu variabel potensi akal (X) dan variabel kreativitas belajar (Y). Berdasarkan tabel tersebut diperoleh nilai probabilitas Sig.(2-tailed) lebih kecil dari 0,05 yaitu $0,000<0,05$, maka Ho ditolak. Artinya ada hubungan yang signifikansi antara potensi akal dengan kreativitas belajar siswa bidang studi pendidikan agama Islam.Hasil korelasi ini sekaligus menjawab hipotesis penelitian dan membuktikan secara empiris bahwa ada hubungan potensi akal dengan kreativitas belajar siswa bidang studi pendidikan agama Islam di SMK KANSAI Pekanbaru.

Kemudian untuk melihat seberapa besar hubungan antara variabel potensi akal (X) dengan variabel kreativitas belajar siswa bidang studi pendidikan agama Islam (Y) dapat dilihat dari nilai pearson correlation yaitu sebesar 0,908. Jadi hubungan antara potensi akal dengan kreativitas belajar siswa bidang studi pendidikan agama Islam di SMK KANSAI Pekanbaru 
sebesar 0,908. Selanjutnya untuk melihat tingkat hubungan tersebut dapat dilihat pada tabel interpretasi koefisien korelatif berikut :

Tabel 9 :Interpretasi Koefisien Korelatif Potensi Akal dan Kreativitas Belajar Siswa Bidang Studi Pendidikan Agama Islam di SMK KANSAI Pekanbaru Interval Koefisien

$$
\begin{aligned}
& 0,80-1,000 \\
& 0,60-0,799 \\
& 0,40-0,599 \\
& 0,20-0,399 \\
& 0,00-0,199
\end{aligned}
$$

Tingkat Hubungan

Nilai 0,908 pada interval koefisien korelasi terletak direntang 0,80 - 1,000 dengan kriteria tingkat hubungan sangat kuat. Ini artinya tingkat hubungan antara potensi akal dengan kreativitas belajarsiswa bidang studi pendidikan agama Islam di SMK KANSAI Pekanbaru adalah sangat kuat.

\section{Interpretasi Data}

Interpretasi data ini dilakukan untuk mengaitkan antara hasil temuan dengan teori yang ada. Penulis akan memaparkan hasil temuan pada penelitian yang telah penulis lakukan.

Berdasarkan analisis data yang dilakukan, dapat diketahui bahwa ada hubungan potensi akal dengan kreativitas belajar siswa bidang studi pendidikan agama Islam di SMK KANSAI Pekanbaru. Hal ini sejalan dengan hasil analisis korelasi pearson moment diperoleh nilai signifikansi lebih kecil dari 0,05 yaitu $0,000<0,05$, maka hipotesis penelitian diterima. Artinya ada hubungan yang signifikansi antara potensi akal dengan kreativitas belajar siswa bidang studi pendidikan agama Islam di SMK KANSAI Pekanbaru. Besarnya tingkat hubungan potensi akal dengan kreativitas belajar siswa bidang studi pendidikan agama Islam tersebut dapat dilihat dari nilai probabilitas pearson correlations yaitu sebesar 0,908 . Ini artinya terdapat hubungan yang sangat kuat antara potensi akal
Sangat Kuat

Kuat

Cukup Kuat

Rendah

Sangat Rendah dengan kreativitas belajar siswa bidang studi pendidikan agama Islam di SMK KANSAI Pekanbaru.

Hasil penelitian ini menunjukkan bahwa potensi akal memiliki peranan penting dalam membentuk kreativitas belajar siswa bidang studi pendidikan agama Islam. Potensi akal siswa yang bisa tampak sejak dini pada peserta didik yaitu; mudah menangkap pelajaran, mempunyai ingatan yang kuat, mempunyai logika dan keterampilan analisis yang kuat, mampu berfikir abstrak, mampu membaca tata letak, mempunyai keterampilan mekanis, mempunyai keterampilan dan seni, pintar bersosialisasi mampu memahami perasaan manusia, dan cepat memecahkan soal atau masalah. Potensi akal adalah kemampuandasarmanusiayang telah diberikan

olehAllahSWTsecaraotomatisyang mempunyai

kecenderunganuntukdapatberkembang dan dapat dikembangkan melalui daya (akal) yang dimiliki oleh manusia.Oleh sebab itu siswa harus bisa mengembangkan potensi akal yang diberikan oleh Allah SWT pada dirinya, dalam membentuk kreatifitas belajar siswa itu sendiri.

Dirmandan Cicih Juarsih memandang potensi sebagai kemampuan yang dimiliki setiap pribadi/individu peserta didik yang mempunyai kemungkinan untuk 
dikembangkansehingga dapat menjadi kemungkinan yang aktual dan berprestasi.Potensi akal yang dimiliki oleh siswa pada dasarnya untuk mengembangkan kreativitas belajar siswa bidang studi pendidikan agama Islam.

Seseorang yang mngembangkan potensi akal dengan baik kemungkinan besar ia akan berhasil dalam kehidupan dan memiliki motivasi untuk berprestasi, sedangkan seseorang siswa yang tidak dapat mengembangkan potensi akal dengan baik kemungkinan besar ia tidak akan berhasil dalam kehidupannya. Akibatnya kreativitas belajar siswa dan prestasi belajarnya tidak akan maksimal. Dengan demikian dapat juga dikatakan bahwa pembentukkan kreativitas belajar akan dapat terbentuk dengan baik apabila didukung dengan kemampuan dalam mengembangkan potensi akal yang dimiliki oleh seseorang. Dengan demikian, maka kreativitas belajar siswa pun akan terbentuk dengan baik apabila didukung dengan potensi akal yang baik juga karena kreativitas belajar seorang siswa sangat berhubungan erat dengan potensi akalnya.

\section{SIMPULAN}

Berdasarkan analisis data yang telah penulis lakukan, maka dapat disimpulkan bahwa ada hubungan potensi akal dengan kreativitas belajar siswa bidang studi pendidikan agama Islam di SMK KANSAI Pekanbaru. Hal ini sejalan dengan hasil analisis korelasi pearson moment diperoleh nilai signifikansi lebih kecil dari 0,05 yaitu $0,000<0,05$, maka hipotesis penelitian diterima. Artinya ada hubungan yang signifikansi antara potensi akal dengan kreativitas belajar siswa bidang studi pendidikan agama Islam di SMK KANSAI Pekanbaru. Besarnya tingkat hubungan potensi akal dengan kreativitas belajar siswa tersebut dapat dilihat dari nilai probabilitas pearson correlations yaitu sebesar 0,908 , berada direntang 0,80 - 1,000. Ini artinya hubungan potensi akal dengan kreativitas belajar siswa bidang studi pendidikan agama Islam di SMK KANSAI Pekanbaru adalah sangat kuat.

\section{DAFTAR RUJUKAN}

Al - Qur'an dan Terjemah. 1989. Departemen Agama Republik Indonesia. Jakarta: CV. Toha Putra Semarang.

Ali, Mohammad dan Asrori, Mohammad. 2012. Psikologi Remaja. Jakarta: PT Bumi Aksara.

Ancok, Djamaludin dan Suroso, Fuad Ansori. 2011. Psikologi Islam. Yogyakarta: Pustaka Pelajar.

Anshari, Hafi. 1996. KamusPsichologi. Surabaya:UsahaNasional.

Arikunto, Suharsimi. 2006. Prosedur Penelitian Suatu Pendekatan Praktek. Jakarta: Reneka Cipta. 2013. Prosedur Penelitian

Suatu Pendekatan Praktek. Jakarta: Reneka Cipta.

Aunurrahman. 2013. Belajar dan Pembelajaran. Bandung: Alfabeta.

Budiningsih, Asri. 2012. Belajar dan Pembelajaran. Jakarta: Rineka Cipta.

Daryanto. 1994. Kamus Besar Bahasa Indonesia (KBBI). Surabaya: Apollo.

Dairi, Rizal. 2010. Metodologi Penelitian. Pekanbaru: UIR Pres.

Dirman dan Juarsih, Cicih. 2014. Pengembangan Potensi Peserta Didik. PT. Rineka Cipta.

E. de Bono. 2008. Metode Mencetuskan Ide -Ide Cerdas, Orisinal dan Kreatif. Jogjakarta: Tink.

Hamid, Muhammad. 2004. Pedoman Diagnostik Potensi Peserta Didik. Jakarta: Departemen Pendidikan 
Nasional.

Hasbullah. 2005. Dasar-dasar IImu Pendidikan, Cet ke-4. Jakarta: PT RajaGrafindo Persada. 2012. Dasar-dasar IImu Pendidikan. Jakarta: PT RajaGrafindo Persada.

Hurlok, Elizabet B., 2002. Perkembangan Anak jilid 2. Jakarta: Erlangga.

Munandar, Utami. 2007. Pengembangan Kreativitas Anak Berbakat. Jakarta: PT. Rineka Cipta. 1992. Pengembangan Kreativitas Anak Berbakat. Jakarta: PT. Rineka Cipta. 1999. Pengembangan Kreativitas Anak Berbakat. Jakarta: PT. Rineka Cipta.

Munawwir, Ahmad Warson. tt. Qamus 'Araby-Indonesia. Yogyakarta:Krapyak. Nasution, Harun. 1982. Teori Islam (Aliran-aliran Sejarah Analisa Perbandingan). Jakarta: UI Press.

Priyatno, Duwi. 2014. Pengolahan Data terpraktis. Yogyakarta: CVAndi Offset.

Purwanto, Ngalim. 2003. Psikologi Pendidikan. Bandung: PT. Remaja Rosdakarya.

Rachmawati, Yeni dan Kurniati, Euis. 2011. Strategi Pengembangan Kreativitas Pada Anak Usia Taman Kanak -kanak. Jakarta: PT Fajar Interpratama Offset.

Slameto. 2010. Belajar dan FaktorFaktor Yang Mempengaruhinya ,cet.ke-4.Jakarta, Rineka Cipta.

Sardiman, A.M., 2014. Intraksi Dan Motivasi Belajar Mengajar. Jakarta: CV. Rajawali.

Sugiono. 2013. Metode Penelitian Administrasi. Bandung: Alfa Beta.
Syah, Muhibbin. 2003. Psikologi Belajar. Jakarta: PT RajaGrafindo Persada.

Tohirin. 2005. Psikologi Pembelajaran Pendidikan Agama Islam. Jakarta: Raja Grafindo Persada.

\section{SKRIPSI:}

Herlina, Skripsi, Pengaruh Konsep diri Terhadap Akhlak Siswa/ i di SMP 4 Siak Hulu Kabupaten Kampar, Universitas Islam Riau, Pekanbaru: 2013.

Sudaryani, Skripsi, Hubungan Kecerdasan Emosiaonal Dengan Prestasi Belajar siswa mata Pelajaran Pendidikan Agama Islam SMA YLPI, Universitas Islam Riau, Pekanabaru: 2012.

Jurnita, Hubungan Kecerdasan Emosiaonal Denganakhlak Terpuji siswa madrasah Aliyah Swasta (MAS) Masmur Pekanbaru, Universitas Islam Riau: 2013

\section{TESIS}

Kadar Bin Muhammd Yusuf, Dimensi Rohani dan Penganruhnya Terhadap Perilaku Manusia Menurut Ibn Sina Dan Al-Ghazali Suatu Kajian Analisis Menurut Perspektif Al-Qur'an, UKM: 2015.

Wismanto, Persepektif Muhammada Iqbal Tentang Potensi Sumber Daya Manusia Dan Pengembangannya Dalam Pendidikan Menuju Masyarakat Muslim Ideal, UIN SUSKA: 2015. 